\title{
Idarucizumab administration in a patient with incarcerated bowel hernia
}

\author{
Ersin Doğanözüa, Ilker Sahin ${ }^{a}$, Emir Karacaglar ${ }^{b}$, Senem Has Hasircic, \\ Mehmet Zeki Buldanlıd
}

\author{
a Department of Cardiology, Çankırı State Hospital, Kırkevler Mahallesi, Kastamonu Caddesi, 18100 Merkez/Çankırı MerkezI \\ Çankırı, Turkey \\ ${ }^{b}$ Department of Cardiology, Başkent University Faculty of Medicine, Ankara Hospital, Fevzi Çakmak Cd. 10. Sk. No:45, \\ Bahçelievler Ankara, Turkey \\ ' Yenimahalle State Hospital, Department of Cardiology, Yeni Batı Mah., 2026. Caddesi, 2367 Sokak No:4, 06370 Batıkent \\ YenimahallelAnkara, Turkey \\ ' Çankırı State Hospital, Department of General Surgery, Kırkevler Mahallesi, Kastamonu Caddesi, 18100 Merkez/Çankırı \\ Merkez/Çankırı, Turkey
}

\section{ARTICLE INFO}

\section{Article history:}

Submitted: 6. 7. 2018

Received in revised form: 1. 9. 2018

Accepted: 21. 9. 2018

Available online: 25. 11. 2019

Klíčová slova:

Antidota

Antikoagulancia

Fibrilace síní

\section{SOUHRN}

Fibrilace síní představuje celosvětově nejčastější poruchu srdečního rytmu. V léčbě fibrilace síní se používají perorální antikoagulancia. Vzhledem $\mathrm{k}$ jejich vyšší účinnosti a bezpečnosti ve srovnání s klasickou léčbou warfarinem se častěji podávají prímá perorální antikoagulancia. Absence antidota k většině perorálních antikoagulancií nové generace do jisté míry ztěžuje jejich použitelnost v klinické praxi. Látka idarucizumab, která byla nedávno uvedena na trh, se používá k rušení účinku dabigatranu v př́padech letálního krvácení nebo při akutních chirurgických a invazivních výkonech. Zatím je nicméně k dispozici pouze málo údajů o její účinnosti a bezpečnosti u geriatrických pacientů. $V$ této kazuistice popisujeme prípad úspěšného použití idarucizumabu u geriatrického nemocného s uskřinutou ventrální kýlou.

(C) 2019, ČKS.

\section{ABSTRACT}

Atrial fibrillation is the most common rhythm disorder worldwide. Oral anticoagulants are used in the treatment of atrial fibrillation. Non-vitamin $\mathrm{K}$ oral anticoagulants have been used more often because of the fact that they are more effective and safer than conventional warfarin therapy. The absence of antidote in the majority of new generation oral anticoagulants leads to some difficulties in clinical usage. Idarucizumab,

Keywords:

Anticoagulants

Antidotes a recently introduced drug, is used in reversing the dabigatran effect in cases of lethal bleeding or acute surgery and invasive procedures. However, little data are available on the efficacy and safety of idarucizumab in geriatric patients. Here, we present a case of the successful administration of idarucizumab in a geriatric Atrial fibrillation

Address: Ersin Doğanözü, MD, Department of Cardiology, Çankııı State Hospital, Kırkevler Mahallesi, Kastamonu Caddesi, 18100 Merkez/Çankırı Merkez/Çankırı, Turkey, e-mail: ersindoganozu@gmail.com DOI: 10.1016/j.crvasa.2018.09.008 


\section{Introduction}

Atrial fibrillation (AF) is one of the leading causes of stroke worldwide. Oral anticoagulant (OAC) therapy is reported to prevent a majority of ischaemic strokes in patients with $\mathrm{AF}$ and facilitate in reducing mortality. ${ }^{1}$ The anticoagulant effect of warfarin, a traditional OAC used to prevent stroke, can be quickly reversed in case of bleeding or urgent surgeries. The most common reason to terminate warfarin therapy are bleeding events, high monitoring efforts and dose adjustment. Recently, the use of non-vitamin K antagonist oral anticoagulants (NOAC) has rapidly increased, ${ }^{2}$ offering suitable warfarin substitution for stroke prevention in patients with AF. Among NOAC's, only dabigatran, a direct thrombin inhibitor, has a specific antidote to reverse anticoagulant effect. Recently, the use of idarucizumab has been initiated in cases of lethal bleeding or acute surgical settings to reverse the dabigatran effect. ${ }^{3}$

Here, we present a case of a successful administration of idarucizumab to reverse the dabigatran effect in a patient who required urgent surgery because of incarcerated bowel hernia.

\section{Case report}

An 84-year-old woman with constipation and abdominal pain was admitted to our emergency service. She was constipated for four days and had experienced the abdominal pain for $24 \mathrm{~h}$. Her medical history comprised hypertension, diabetes and chronic AF. The cardiac examination was unremarkable, except for arrhythmic heart beats. Electrocardiogram revealed rate-controlled narrow-complex AF. She had been consuming diltiazem (60 mg once a day) and dabigatran (110 mg twice a day). Her laboratory findings were normal, except for the coagulation parameters. In addition, her INR was 1.4 (aPTT: $41.1 \mathrm{~s}$ and PT: $18.1 \mathrm{~s}$ ). Her creatinine clearance was $53 \mathrm{ml} / \mathrm{min} / 1.73 \mathrm{~m}^{2}$. We suspected to incarcerated hernia on physical examination. Abdominal tomography was performed to confirm diagnosis and exclude mesenteric ischemic event. Based on these findings, the patient was diagnosed with incarcerated bowel hernia. Accordingly, we scheduled an urgent surgery. She took the last 110 mg dabigatran dose $6 \mathrm{~h}$ before the surgery, and idarucizumab ( $2 \times 2.5 \mathrm{mg}$ ) was administrated in $10 \mathrm{~min}$. Lastly, the patient underwent abdominal surgery after $100 \mathrm{~min}$.

We performed the combined spinal-epidural block, and the surgery lasted for $75 \mathrm{~min}$. Notably, we did not perform intestinal resection. We encountered no bleeding complication during the surgery. After the operation, her INR was 1.3 (aPTT: $22.6 \mathrm{~s}$ and PT: $17.2 \mathrm{~s}$ ). After postoperative two days, the patient was discharged without any complication and with the prescription of dabigatran (110 mg twice a day).

\section{Discussion}

As the number of users of NOAC has increased, the need for the reversal of the anticoagulant effect of NOACs is anticipated to increase. Although NOACs are more fre- quently used in geriatric patients, these are not adequately represented in NOAC trials because of low number of elderly participants and some exclusion criteria (etc. presence of a severe heart-valve disorder, increased the risk of hemorrhage, a creatinine clearance of less than $30 \mathrm{ml}$ per minute). ${ }^{4}$ If creatinine clearance is normal, the termination of the dabigatran effect is anticipated within 12-24 $\mathrm{h}$ after the last dose. ${ }^{5} \mathrm{~A}$ study has recommended delaying elective surgeries for a minimum of $12-24 \mathrm{~h}$ to reduce the bleeding risk. ${ }^{2}$ However, some clinical situations, including lethal bleeding, urgent surgeries or urgent interventions, necessitate the use of specific reversal agents for a quick reversal of the anticoagulant effect of NOACs. Our patient underwent combined spinal-epidural block anaesthesia and a successful abdominal surgery without any bleeding complication after the reversal of the anticoagulant effect of dabigatran under idarucizumab administration.

\section{Conclusion}

This case highlights the efficacy and safety of idarucizumab in urgent settings and the importance of selecting an anticoagulant with a specific antidote in daily clinical practice. Nevertheless, more studies accumulating reallife data are warranted to develop specific anticoagulation reversal protocols.

\section{Conflict of interest}

None declared.

\section{Funding body}

None.

\section{Ethical statement}

Authors state that the research was conducted according to ethical standards.

\section{Informed consent}

We have informed consent from the patient for publication of the case and we are grateful to the patient and her family for their cooperation. We also declare that there is no image or clue that will enable her identity to come out.

\section{References}

1. Lip GY, Laroche C, loachim PM, et al. Prognosis and treatment of atrial fibrillation patients by European ESC Guidelines 2955 cardiologists: one year follow-up of the EURObservational Research Programme-Atrial Fibrillation General Registry Pilot Phase (EORP-AF Pilot registry). Eur Heart J 2014;35:3365-3376.

2. Heidbuchel $H$, Verhamme $P$, Alings $M$, et al. Updated European Heart Rhythm Association Practical Guide on the use of non-vitamin $\mathrm{K}$ antagonist anticoagulants in patients with non-valvular atrial fibrillation. Europace 2015;17:1467-1507.

3. Pollack CV Jr, Reilly PA, Eikelboom J, et al. Idarucizumab for dabigatran reversal. N Engl J Med 2015;373:511-520.

4. McMurray JJ, Adamopoulos S, Anker SD, et al. ESC Guidelines for the diagnosis and treatment of acute and chronic heart failure. Eur Heart J 2012;14:803-869.

5. Stöllberger C, Ulram A, Bastovansky A, Finsterer J. Traumatic fatal cerebral haemorrhage in an old patient with a history of multiple sclerosis under dabigatran: a case report and review of the literature. J Geriatr Cardiol 2015;12:83-87. 